Cahiers $d u$ MONDE RUSSE

\section{Cahiers du monde russe}

Russie - Empire russe - Union soviétique et États indépendants

42/2-4 | 2001

La police politique en Union soviétique, 1918-1953

\title{
The passport system and state control over population flows in the Soviet Union, 1932-1940.
}

\section{Gijs Kessler}

\section{OpenEdition}

Journals

Édition électronique

URL : https://journals.openedition.org/monderusse/8464

DOI : 10.4000/monderusse.8464

ISSN : $1777-5388$

\section{Éditeur}

Éditions de l'EHESS

\section{Édition imprimée}

Date de publication : 1 avril 2001

Pagination : 477-504

ISBN : 2-7132-1398-3

ISSN : $1252-6576$

Référence électronique

Gijs Kessler, "The passport system and state control over population flows in the Soviet Union 1932-1940. », Cahiers du monde russe [En ligne], 42/2-4 | 2001, mis en ligne le 01 janvier 2007, consulté le 02 septembre 2022. URL : http://journals.openedition.org/monderusse/8464; DOI : https://doi.org/10.4000/monderusse.8464 
chercher : repérer : avancer

Cet article est disponible en ligne à l'adresse :

http://www.cairn.info/article.php?ID REVUE=CMR\&ID NUMPUBLIE=CMR 422\&ID ARTICLE=CMR 4220477

The passport system and st ate control over population flows in the Soviet Union, 1932-1940

\section{par Gij s KESSLER}

\section{Editions de l'EHESS | Cahiers du monde russe}

2001/2-3-4 - Vol 42

ISSN 1252-6576 | ISBN 2713213983 | pages 477 à 504

Pour citer cet article :

-KESSLER G., The passport system and state control over population flows in the Soviet Union, 1932-1940, Cahiers du monde russe 2001/2-3-4, Vol 42, p. 477-504.

Distribution électronique Cairn pour les Editions de l'EHESS.

(C) Editions de l'EHESS. Tous droits réservés pour tous pays.

La reproduction ou représentation de cet article, notamment par photocopie, n'est autorisée que dans les limites des conditions générales d'utilisation du site ou, le cas échéant, des conditions générales de la licence souscrite par votre établissement. Toute autre reproduction ou représentation, en tout ou partie, sous quelque forme et de quelque manière que ce soit, est interdite sauf accord préalable et écrit de l'éditeur, en dehors des cas prévus par la législation en vigueur en France. Il est précisé que son stockage dans une base de données est également interdit. 
GIJS KESSLER

\section{THE PASSPORT SYSTEM AND STATE CONTROL OVER POPULATION FLOWS IN THE SOVIET UNION, 1932-1940*}

One of the aspects of police control in the Soviet Union that the recent opening-up of the archives has shed new light on, is the restrictive system of internal passports and urban residence permits that was in existence from 1932 on. For the period this article is concerned with, i.e. the 1930s, part of the files of the Central Police Administration and the OGPU/NKVD, which administered the passport system from the moment of its creation on, has been made accessible to historians, and an important body of materials from the still closed Presidential Archive has been published in the journal Istochnik. ${ }^{1}$ Recent research, furthermore, has revealed the central role that the passport system fulfilled in policing the urban population during the 1930s, both in the years leading up to the Great Terror of 1937-1938 and afterwards. ${ }^{2}$ A number of publications with a regional focus have devoted attention

* Earlier versions of this paper were presented at the annual conference of the British Association for Slavonic and East-European Studies (BASEES), Fitzwilliam College, Cambridge, 1-3 April 2000, and at the conference "The role of the political police in the Soviet Union, 1918-1956," Maison des Sciences de l'Homme, Paris, 25-27 May 2000.

1. This concerns that part of the NKVD and police-archives that is stored in the State Archive of the Russian Federation (GARF), as opposed to the archive of the NKVD-successor organisation FSB. Surprisingly, the files of the Central Police Administration (GURKM Glavnoe Upravlenie Raboche-Krest'ianskoi Militsii, f. R-9415), that was strictly speaking responsible for the running of the passport system, seem to contain less materials on passport matters than the NKVD fond itself (f. R-9401). Unfortunately, I have not been able to use this latter fond, because it was temporarily inaccessible at the time of my archival research, but as the materials on passports it contains have been used by other authors, I have been able to use the main insights derived from them for the benefit of this article. For the materials on the passport system from the Presidential Archive, cf. ""Izmeneniia pasportnoi sistemy nosiat printsipial'no vazhnyi kharakter". Kak sozdavalas' i razvivalas' pasportnaia sistema v strane," Istochnik, 6 (1997): 101-121.

2. P. Hagenloh, "SSocially harmful elements" and the Great Terror," in S. Fitzpatrick, ed., Stalinism. New directions (London, 2000): 286-308. 
to the actual process of what was called the "passportisation" of the towns in 19331934, i.e. the handing out of passports and residence permits and the widespread social cleansing that accompanied it. ${ }^{3}$ Also, it has been shown ever more clearly than before that, after this initial phase of outright passportisation, the passport system was in practice much less restrictive than has often been assumed, and that rural-urban migration was all but halted in 1932.4

With a few noteworthy exceptions, however, the standing interpretation on the origins of the passport system and the reasons why it was introduced in 1932, have not been questioned. ${ }^{5}$ Roughly speaking, the traditional view of the passport system is that it was introduced in 1932 to stop the influx of starving peasants to the towns, and to tie the peasantry more closely to the kolkhozy and the land, principally by withholding passports to the rural population. Often an analogy is noted to the system of internal passports that existed under the tsars, overlooking the fact that there was a marked difference in functionality between the two. Whereas the tsarist system of internal passports served to keep control over peasants that migrated to the towns, and to keep them embedded in and committed to rural society, the Soviet system was exclusively concerned with control over the urban and non-rural population. ${ }^{6}$ The aim of this article is to re-examine the origins and the aims of the passport system through a comprehensive analysis of the way in which the system really functioned during the 1930 s, and of the changes in functionality that can be observed in the course of the decade. What I will argue is that the passport system had from the very outset been meant in the first place as an instrument of repression and police control, and in the short run even more crudely as a purging tool. To understand why the Bolshevik leadership deemed it necessary to resort to measures of this sort, it is essential to see the introduction of the passport system in close conjunction with the severe crisis of the years 1932-1933.

3. S. Yekelchyk, "The making of a "proletarian capital": Patterns of Stalinist social policy in Kiev in the mid-1930s," Europe-Asia Studies, 50, 7 (1998): 1232-1235; E. N. Chernolutskaia, "Pasportizatsiia dal'nevostochnogo naseleniia (1933-1934)," Revue des Études slaves, 71, 1 (1999): 17-33; K. Gerasimova, S. Chuikina, "Ot kapitalisticheskogo Peterburga k sotsialisticheskomu Leningradu: izmenenie sotsial'no-prostranstvennoi struktury goroda v 30 e gody," in: T. Vikhavainen, ed., Normy i tsennosti povsednevnoi zhizni: Stanovlenie sotsialisticheskogo obraza zhizni v Rossii, 1920-1930e gody (SPb, 2000): 36-37.

4. S. Fitzpatrick, "The great departure. Rural-urban migration in the Soviet Union, 1929-1933," in: W. Rosenberg, L. Siegelbaum, eds, Social dimensions of Soviet industrialisation (Bloomington, 1993): 15-40, and, in the same volume: S. Kotkin, "Peopling Magnitostroi. The politics of demography" (ibid.: 63-104).

5. The first and principal article challenging the existing interpretation on the introduction of the passport system is: Nathalie Moine, "Passeportisation, statistique des migrations et contrôle de l'identité sociale," Cahiers du Monde russe, 38, 4 (octobre-décembre 1997): 587-600.

6. For a good analysis of the way in which the tsarist passport system served to keep peasant migrants committed to the rural world and the obshchina, cf. J. Burds, Peasant dreams and market politics, labor migration and the Russian village, 1861-1905 (Pittsburgh, 1998): 56$61 \mathrm{FF}$. 


\section{The crisis of 1932}

The crisis of 1932-1933 was an almost direct result of the deliberate strategy of unequal development of the urban and rural sector of the economy that had lain at the heart of the industrialisation effort of preceding years. It was a policy of unequal development that aimed at exploiting the rural sector for the benefit of the urban industrial sector through what was called "primitive socialist accumulation in the countryside." During the first five-year plan these exploitative policies had been pushed to such extremes that by 1932 a major rural crisis unfolded, which, in its turn, had an impact on the urban sector of the economy. The central issue around which the crisis of 1932-1933 revolved, was food, and with it, food-supply.

The collectivisation of agriculture, combined with the ensuing merciless extraction of grain and other crops for three years in a row, had undermined the productive capacity of the villages to the point, where, in 1932, the rural population could not and would no longer meet the delivery targets set out by the state. ${ }^{7}$ This led to a major confrontation between the Bolshevik regime and the peasantry. From the early spring of 1932 on, and following the announcement of the very high procurement plan for the 1932 harvest, unrest started to spread in the villages. Massive walk-outs from the kolkhozy were reported by the OGPU, as well as frequent work-stoppages, go-slow-strikes, and the disbanding of entire kolkhozy by peasants who decided to go "individual" again. ${ }^{8}$ The party leadership was not prepared to back down, though. To start with, it desperately needed the grain it had planned to collect, both for export that would enable it to repay foreign loans taken out at the end of 1930 and the start of 1931, and, secondly, to feed an urban population that had mushroomed over the three preceding years due to a rapid expansion of the industrial workforce. Yet, it was not just that the party and state leadership could not lower procurement targets; it was also in no way whatsoever prepared to yield to what it called "peasant sabotage." The Bolshevik resolution to push through the 1932 procurement plan, and to teach the peasantry the hard way that "state interests come first," set the scene for the confiscation of too large a part of the 1932 harvest and the depletion of most other rural food reserves. The tragic results for the rural population are well known and speak for themselves.

What concerns us here is the fact that, even after collecting all possible grain reserves that could be scraped together, the party leadership still found themselves with an amount of grain that was considerably smaller than what they had counted

7. Traditionally, historiography has always stressed the inability of the rural population to meet the 1932 procurement plan. In a recent article, though, it is argued convincingly that the breakdown of agricultural production in 1932 was also caused at least partly by a refusal of the kolkhoz population to work for the state any longer. Cf. D'Ann R. Penner, "Stalin and the Ital'ianka of 1932-1933 in the Don region," Cahiers du Monde russe, 39, 1-2 (janvier-juin 1998): 27-68. For an overall analysis of state-peasant relations in those years, cf. A. Graziosi, The great Soviet Peasant War. Bolsheviks and peasants, 1917-1933 (Cambridge, MA: Harvard UP, 1996).

8. Rossiiskii Gosudarstvennyi Arkhiv Ekonomiki (RGAE), f. 7486 (NKZ SSSR), op. 37s, d. $239,11.27-29,46$ 
on. Leaving aside the export plan, the state faced an acute problem in feeding the urban population, the workers and the army, in short, those groups in society that were essential for either the industrialisation effort or the survival of Bolshevik rule. This was not just an abstract, but instead a very real problem. Having introduced rationing in 1928-1930, the state had taken upon itself the task of supplying the urban population with food and other essentials. ${ }^{9}$ Even before the food crisis of 1932 this had already proven to be a daunting task, not in the last place because of the fact that the period of the first five-year plan had witnessed an increase of the urban population that surpassed all expectations. The constant exhortations to industry to produce more, regardless of increases in productivity, had led to a rapid expansion of the industrial and urban workforce as enterprises drew in more and more labour in order to compensate for shortfalls in productivity. From the supply side this process was fed by a constant stream of rural dwellers that sought to escape forced collectivisation and "dekulakisation," in short that sought to escape a countryside in the throes of the violence and terror of "primitive socialist accumulation." 10 This largely unplanned and hence unaccounted for influx into the towns put a growing pressure on the system of urban rationing. By 1932, when the effects of the destruction of the productive capacity of the agricultural sector started to make themselves felt, the state had come to face increasing difficulties in providing even those meagre rations it had been handing out before. Thus, the strategy of unequal development of agriculture and industry had come to the point where the "squeezing" of the rural sector started to have a backlash on the urban and industrial sector in the form of a disruption of the supply links running from village to town. ${ }^{11}$

Typically for those days, the country's leadership refused to acknowledge its responsibility for the growing crisis, and instead put the blame elsewhere; in this case on enterprise managers who were "found" to be "squandering scarce food reserves," as well as on "anti-social" and "kulak" elements that were making widespread misuse of the urban rationing system by cashing in double or even triple rations. ${ }^{12}$ The authorities' response was twofold. To start with, they attempted to cast off part of their responsibility for urban food-supply. In the early spring of 1932 non-working family members were thrown out of the distribution system and the categories of foodstuffs that were subject to rationing were drastically reduced..$^{13}$

9. Cf. E. Osokina, Za fasadom "stalinskogo izobiliia”(Moscow, 1998): 37-85.

10. G. Kessler, "Krest'ianskaia migratsiia v Rossiiskoi imperii i Sovetskom Soiuze. Otkhodnichestvo i vykhod iz sela," in: Sotsial'naia istoriia. Ezhegodnik 1998-1999 (Moscow: ROSSPEN, 1999): 323-324.

11. For illustrations of food-shortages and lack of rationed foodstuffs in the towns of various regions, cf. A. Graziosi, ed., Lettere da Kharkov. La carestia in Ucraina e nel Caucaso del Nord nei rapporti dei diplomatici italiani, 1932-1933 (Torino: Einaudi, 1991): 95, 109-110, 119, 127.

12. Gosudarstvennyi Arkhiv Sverdlovskoi Oblasti (GASO), f. R-277 (Uralobltruda), op. 2, d. $71,11.31,53$.

13. GASO, f. R-241 (Uralplan), op. 2, d. 2002, 1. 89ob; S. Schwarz, Labor in the Soviet Union (New York, 1951): 140. 
Secondly, an effort was launched to tighten control over urban distribution in order to root out fraud with rationing cards as well as other forms of abuse of the system. In early October 1932 a decree was sent out to the localities that aimed at making access to rationing dependent upon official urban residence, and that called for increased efforts to enforce mandatory registration of urban residents for this purpose. ${ }^{14}$ A nation-wide inquiry into the reliability of the system of population registration in the towns brought to light, though, that there was little connection, both in terms of numbers and in terms of actual persons concerned, between those registered as residents and those actually being residents. ${ }^{15}$

Meanwhile, the crisis deepened. As the all-out confrontation between the state and the peasantry over the 1932 harvest began to yield its first tragic results, starving peasants started to flee from the areas affected by famine in ever larger numbers. Part of this exodus was directed towards the towns, most likely because that was where people expected the grain that had been requisitioned for years to be. In August 1932 large-scale mopping-up operations were reported from Moscow and Kharkov, with scores of homeless beggars and starving peasants being thrown out and denied further access at the risk of immediate, on-the-spot shooting. ${ }^{16}$ The violent nature of the regime's response must be understood against the background of a growing and deepening unease about the outcome of the bitter struggle with the peasantry that was going on. After all, the massive unrest in the countryside of the spring of 1930, when an armed peasant regiment had been marching on the town of Kislovodsk, was less than three years ago, and with the recollections of that struggle still fresh in mind, many within the country's leadership must have found a repetition of those events not entirely hypothetical, particularly given the fact that in the current conflict the stakes were much higher for the rural population.

What made the matter even worse in comparison with 1930, was that the "enemy" was now much more dispersed, and no longer confined to the countryside only. To start with, part of the rural population that had been labelled as "kulaks" had managed to escape dekulakization by fleeing from the villages and settling down elsewhere under assumed identities. Furthermore, three years of intensive urbanisation had brought hundreds of thousands, if not millions of peasants into the urban and industrial workforce, and the Bolshevik leaders were very much aware, because meticulously informed by the OGPU reports, that these migrants had come predominantly from the non-kolkhoz part of the population, in other words from that part of the peasantry that was either not allowed to or not willing to join the kolkhozy. ${ }^{17}$ This made them an a priori suspicious category in the eyes of the regime; what else could a peasant that did not join the kolkhozy be but a "kulak," a

14. S. Kotkin, art. cit.: 88 .

15. Gosudarstvennyi Arkhiv Rossiiskoi Federatsii (GARF), f. A-374 (TsSU RSFSR), op. 23, d. 198, 11. 1-227.

16. A. Graziosi, ed., Lettere..., op. cit.:109-110.

17. RGAE, f. 7486 (NKZ SSSR), op. 37s, d. 193, 11. 98-100; d. 236, 1. 11; GARF, f. R-5515 (NKT SSSR), op. 17, d. 378,1.83. 
"podkulachnik," or at least an "anti-Soviet" element? Knowing that the towns and construction sites had thus been "infiltrated" by the "enemy" seems to have made the party leadership increasingly jittery at a time when they were engaged in a struggle for life and death with this same "enemy" in the Kuban, the Don area, the Ukraine, and all other areas where famine raged. How volatile the situation was in the towns was demonstrated by the cotton workers' strikes that had broken out in the Ivanovo region in April 1932 and bread riots and other disturbances in the Byelorussian town of Borisovo. The disturbances in the Ivanovo region must have seemed particularly threatening to the Bolshevik leadership, because the strikes involved several towns, and provoked work-stoppages in the surrounding countryside in support of the strikers, thus reinforcing Bolshevik anxieties about a possible alliance between the "enemy outside" - a seemingly united peasantry and the "enemy within."18

\section{"Passportisation"}

At the end of 1932 the regime took to the offensive. In an attempt to safeguard the Bolsheviks' main loci of power from the potential danger of further food riots growing into popular uprisings, a set of decrees was launched that aimed at ridding the main strategic towns of "unreliable" elements, at strengthening state control over population flows into these towns through an improved system of population registration, and, as an add-on effect, at relieving some of the pressure on the rationing system by reducing the number of mouths to feed..$^{19}$ The introduction of a system of internal passports and urban residence permits played a central role in this. Its express aim, as formulated by the Politbiuro TsK VKP(b) on 15 November 1932, was to facilitate the cleansing of Moscow, Leningrad and other large cities of "superfluous [people - G.K.], not involved in production or the work of institutions, as well as of kulak-, criminal and other anti-social elements hiding in the towns."20

18. J. J. Rossmann, "The Teikovo cotton workers' strike of April 1932: Class, gender and identity politics in Stalin's Russia," The Russian Review, 56 (January 1997): 44-69; O. V. Khlevniuk, Politbiuro. Mekhanizmy politicheskoi vlasti v 1930-e gody (Moscow, 1996): 5758. The support from the Ivanovo countryside to the strikers was explained by the fact that most of the cotton workers were still connected to the village through an extensive network of family ties. In Borisovo 400-500 people broke open and plundered grain warehouses and organised a demonstration and a march of children and women to Red Army barracks. The demonstrators seemed to have received some support from the local authorities and from the police, as well as from some people in the army units.

19. As far as food supply to the major cities is concerned, this was supplemented by measures of the start of 1933 that set aside large stocks of grain for Moscow and Leningrad; this at a time when the countryside was already in the throes of famine. Cf. A. Graziosi, The great Soviet Peasant War, op. cit.: 38.

20. Cf. Istochnik, 6 (1997): 104. The statement of intention contained in the preamble to the decree was quite summary. In several newspaper editorials over the first months of the year 1933 it was elaborated in more detail on the functions of the passport system in ridding the urban centres of all sorts of "undesirable elements" that were consuming the food meant for honest workers, and occupying scarce living quarters. Cf. S. Fitzpatrick, "The great departure...," art. cit.: 29-30. 
Thus, the passport system was specifically targeting both non-working mouths and "unreliable elements" that could form a risk for Bolshevik power. ${ }^{21}$ In addition, it was to serve the wider aim of improving urban population registration, which, as we recall, had been found to be unreliable. A special commission under the chairmanship of Balitskii, vice-head of the OGPU, was set up to work out the details of the operation.

On 27 December 1932, the decrees prepared by this commission were approved by the Politbiuro. They obliged all citizens over 16 years of age, permanently residing in towns, workers' settlements, sovkhozy, and construction sites to take out a passport and register it with the police in order to obtain a residence permit for the locality they were living in (propiska). From then on, persons found without a valid passport and residence permit in localities where the passport system had been introduced, faced a fine of up to 100 rubles and expulsion by the police, and in cases of repeated offence, penal sanctions. Furthermore a passport had to be shown in order to take up a job in localities where the passport system was in place. The "passportisation" of the urban population had to be carried out in the first place in Moscow, Leningrad, Kharkov, Kiev, Minsk, Rostov and Vladivostok, and was only subsequently to be extended to other urban centres in the course of the year 1933.22

Over the first week of January 1933 the Central Police Department of the OGPU (GURKM) and a commission of the Council of People's Commissars under Avel' Enukidze worked out a detailed instruction that laid down the rules governing the issuing of passports and residence permits in the main cities of the first category, Moscow, Leningrad and Kharkov, as well as within a ring of 100 kilometres around Moscow and Leningrad, and 50 kilometres around Kharkov. The instruction consisted of two parts; one part that was meant for publication, and a second, secret part that had to be sent down to the local police administrations. ${ }^{23}$ On January 14, the instruction entered into force. ${ }^{24}$ The secret part specified the categories of persons that were to be denied a passport and propiska, and that thus, in compliance with the stipulations of the published text, were deprived of the right to live in the areas concerned:

21. It should be noted here that the passportisation and the accompanying social cleansing of the towns were part of a wider purge of society, involving among others the party as well as kolkhoz- and other rural officials. Faced with the disruption and antagonism engendered by the famine-crisis the regime tried to safeguard its position by rounding up large numbers of real and perceived adversaries. At the January 1933 Plenum Stalin explicitly warned for the danger posed by "hidden" adversaries that had wormed their way into respectable jobs and positions and called for a new round of class-war to deal with this "hidden enemy." Cf. the contribution by David Shearer to this issue.

22. Sobranie zakonov i rasporiazhenii raboche-krest'ianskogo pravitel'stva SSSR (hereafter $S Z), 84$ (1932), arts. 516, 517.

23. GARF, f. R-5446 (SNK SSSR), op. 14a, d. 740,11. 101-135.

24. $S Z, 3$ (1933), art. 22. 
"a) persons that are not involved in production or the work of institutions or schools, and that are not engaged in any other form of socially useful work (with the exception of the disabled and pensioners)

b) kulaks or dekulakised persons that have fled from the countryside, even if they are employed at enterprises or soviet institutions

c) persons that have arrived from other towns or from the countryside $[\ldots]$ after 1 January 1931 without a formal invitation to work at an institution or an enterprise, if they are currently without fixed work, or if they are working at an enterprise or institution, but are obvious flitters or have been fired [in the past] for disorganisation of production

d) persons deprived of the right to vote

e) all persons with a criminal record

f) refugees from abroad, with the exception of political emigrants

g) all family members of persons falling into one of the former categories in so far as they are part of the same household." 25

Exempted from these restrictions were specialists, priests of all religious denominations, as well as seasonal workers, the last of which could obtain a temporary residence permit for three months, subject to renewal upon request by the employer. ${ }^{26}$

Although initially limited to the towns of Moscow, Leningrad and Kharkov plus the 50/100 kilometre zones around them, this instruction would subsequently be applied to other towns as well, in so far as they were included in the category of what came to be called "regime towns." On 3 and 5 February for example, the list of towns that had to be "passportised" with the highest priority, was extended with Magnitogorsk, Kuznetsk, Stalingrad, Baku, and others. ${ }^{27}$ On 28 April 1933, this procedure was formalised as part of a decree that extended the passport system to the entire territory of the Soviet Union, with the exception of areas with rural status. Mandatory "passportisation" was introduced for the population of all towns, workers' settlements, raion-centres and a 100-kilometre zone inwards from the western border of the Soviet Union, as well as for those working or living at construction sites, industrial enterprises, in transport, on sovkhozy and in population centres that contained Machine \& Tractor Stations (MTS). The issuing of passports and residence permits in these areas was to be carried out on the basis of articles 3-10 of the instruction of 14 January, which were those included in the published part of the decree, with the exception of the border-zone and a list of specified towns, where the workings of the entire decree were to be applied, meaning, including the secret part of the instruction. ${ }^{28}$

25. GASO, f. R-854 (URKM UNKVD po Sverdlovskoi oblasti), op. 3, d. 113,1. 11.

26. Ibid. The exemption for seasonal workers on the other hand, was listed in the published part of the decree; Cf. $S Z, 3$ (1933), art. 22.

27. SZ, 11 (1933), arts. 60-61.

28. SZ, 28 (1933), art. 168. 


\section{The cleansing of towns}

In the cities and towns of the first, "regime"-category "passportisation" seems to have started even before the instruction of 14 January 1933 had been properly worked out, and the operation continued well into the late spring of 1933. The campaign was co-ordinated by the Central Police Department of the OGPU and carried out by its regional subdivisions. The OGPU regularly informed the main party and government leaders about the results of the cleansing operation. In Moscow, Leningrad, Kharkov, Magnitogorsk and other cities thousands of people were denied passports and propiska after having been "unmasked" as "flitters," "disorganisers of production," "spekulianty," "former aristocracy," "bandits," "thieves," "recidivists," "white-guardists," "former traders," "baptists," "mensheviks," "zionists," and, above all, "kulaks," "kulaks," and more "kulaks."29 All in all, between January and August 1933, in Moscow alone 65,904 persons were denied a passport and subsequently evicted, and another 79,261 in Leningrad. In percentage terms the number of applications for a passport that were turned down varied considerably from town to town, from around 3\% in Moscow up to $10.2 \%$ in Kiev and $10.9 \%$ in Baku. Allegedly, large amounts of people did not even try to obtain a passport, and left on their own accord, or hid out in cellars, attics and basements, while the towns were in the grip of "passportisation." In Moscow police-raids yielded 85,937 persons without a passport, who were sent off directly to labour camps and work settlements, without passing through court ("v poriadke vnesudebnoi repressii"). According to an OGPU report of 27 August 1933, passportisation reduced the Moscow population by 214,700 persons, and that of Leningrad by $476,182.30$

Even before the purging of the "regime" cities of the first category had been concluded, passportisation was extended to all urban and semi-urban areas as specified in the decree of 28 April 1933. As pointed out above, these towns and settlements were not to be subjected to the rigid form of social cleansing provided for in the secret part of the instruction of 14 January 1933. Indeed, the police was supposed to hand out passports and residence permits to all persons residing there at the moment of passportisation, as well as to part of the population evicted from the regime localities. On 10 April 1933, the Politbiuro underscored once again that all persons who had been refused passports in the towns and zones of the first category

29. GARF, f. R-5446 (SNK SSSR), op. 14a, d. 740, 11. 71-99. In this first phase fugitive "rural elements" seem to have been targeted most heavily.

30. Istochnik, 6 (1997): 107-109. How the OGPU arrived at these figures remains unclear; although both the number of passports issued and the number of persons evicted were apparently known, population registration before passportisation had been very inaccurate, so it must have been impossible to calculate the population decrease in such detail by subtracting the figures on passportisation-related departures from the population figures for a given city or town. Most likely therefore, these figures were not much more than rough estimates, but unfortunately there is no way of checking, given the absence of reliable population statistics for individual cities before passportisation. For the percentages of passport applications that were turned down, cf. N. Moine, art. cit.: 594. 
had the full right to take up residence in any other town or locality of their choice that did not fall into this first category, and ordered the Central Police Department of the OGPU to instruct their regional and local subdivisions to this effect. ${ }^{31}$

However, this dual application of the passport rules sparked off protests from the non-regime areas. All through the late spring, summer and autumn of 1933 requests were coming in with the Council of People's Commissars to include the one or the other town or settlement into the first, "regime"-category in order to allow for a more restrictive issuing of passports on the basis of the criteria laid down in the secret part of the instruction of 14 January 1933. Without any doubt part of these requests were above all attempts to show the sort of revolutionary zeal that was believed to be approved of by the party leadership, but others refer to problems that seem all too real. A good example is a request from the Ukrainian town of Vinnitsa, located at a distance of 100.5 kilometres from the Romanian border, and thus just outside the 100-kilometre border zone falling under the secret instructions of 14 January. This meant that in the town of Vinnitsa passports and residence permits were to be handed out to all persons that applied for one. Fiftyfive out of the sixty-four raiony of the wider Vinnitsa-district were, however, located within the border-zone, and were, as a consequence, cleansed of all "unreliable elements." The result was that a considerable part of the persons that were expelled from the border-zone flowed into the town of Vinnitsa itself to try and obtain a passport and residence permit there. The local authorities frowned upon this influx of "unreliable elements" and begged Sovnarkom to give Vinnitsa regime status, so that it would become possible to deny passports and residence permits to those that had been expelled from the border-zone. A similar situation was reported from the hinterland of Moscow, where the town of Tula saw itself confronted with the influx of considerable numbers of people expelled from Moscow and from the nearby 100-kilometer "regime"-zone around the capital. After consultation with the OGPU most of these requests were turned down, however, save for some exceptions, like that of Vinnitsa. This leads one to infer that the main scope of passportisation had, after all, been the purging of key towns and areas, rather than an all-encompassing social cleansing of the urban population. ${ }^{32}$

Nevertheless, it appears that even in the non-regime localities passportisation involved some purging of "anti-social" and "anti-Soviet elements." When the NKVD presented the balance of the passportisation campaign in August 1934, the report listed a total of 423,438 "socially alien" and "fugitive elements" that had been "unmasked" in the non-regime areas in the course of the campaign. The total number of passports issued was 12,006,987 for the regime category, and $14,942,572$ for the non-regime areas, which would bring the total population over 16 years of age of the passportised areas at around 27 million persons. ${ }^{33}$

\footnotetext{
31. Istochnik, 6 (1997): 106.

32. GARF, f. R-5446 (SNK SSSR), op. 14a, d. 740, 11. 154-156, 159, 161-164, 167-168, 169172; d. 719, 11. 3-7; d. 761, 11. 1-4.

33. N. Werth, G. Moullec, Rapports secrets soviétiques. La société russe dans les documents confidentiels, 1921-1991 (Paris: Gallimard, 1995): 27-34.
} 


\section{Controlling population flows}

A tenacious assumption about the passport system is that it was introduced in 1932 to close off the urban areas for peasant migrants, and to prevent further growth of the towns by imposing administrative limitations on population flows. The roots of this interpretation can be traced back to Soviet works of the 1970s and early 1980s, when the passport system did indeed function to this effect, following the imposition of limitations on settlement for over 70 cities and towns in $1956 .{ }^{34}$ What I argue in this article, however, is that as far as the passport system of the 1930s is concerned, this is a basic misconception.

To start with, from the very outset the passport system did not specifically target urban areas. Rather, the aim was to purge certain key areas, which were deemed to be of strategic importance to the Bolshevik regime in the circumstances of the 1932-1933 crisis. That these were largely urban areas merely reflects the position of the Bolshevik regime at the time of passportisation, operating as it was from an urban "bridgehead" to impose a programme of economic development on the country that was a largely urban vision with a distinct anti-rural flavour to it. As we saw, however, by April 1933, the passportised areas had also come to include a substantial rural element, ranging from the Machine Tractor Stations and the villages they were located in, to the strategic border-zones of the country. Especially in the latter case it comes out quite clearly that passportisation was everything but an exclusively urban operation. In the Far East, large tracts of countryside in the border-zones were passportised as regime areas, and they were cleansed with such zeal that it caused for a momentary upswing in the exodus from these areas to towns deeper into Soviet territory that fell into the non-regime category. .35

But even if one adopts a more narrow perspective, focusing exclusively on the urban areas that were involved in the operation, passportisation imposed limits on migration only in so far as it aimed at tying the influx of people from the countryside more closely to urban industrial employment. Depending on the need for labour from urban-based industries, this could mean both growth and decline of the urban population. Thus, during the first wave of passportisation, which came at a time of scaled-down investment and economic contraction, people found without work seem to have formed the principal category of persons that was evicted from the regime-areas. This is suggested in any case by an August 1933 OGPU report on the passportisation in Moscow and Leningrad, which listed the category of "people having arrived after January 1931 and found without permanent work" as the single largest category among those evicted (41\%). ${ }^{36}$ In the non-regime areas on the other

34. Cf. C. Buckley, "The myth of managed migration: Migration control and market in the Soviet period," Slavic Review, 54, 4 (Winter 1995): 896-916. The work of the Soviet authors that this view is based on is listed in footnote 5 .

35. E. N. Chernolutskaia, art. cit.: 30

36. Istochnik, 6 (1997): 108. 
hand, which came up for passportisation only when the worst of the economic crisis had already passed, passports were to be issued to all inhabitants inclusively.

After the once-over of direct passportisation the passport system came to face a more dynamic task. On the one hand it had to allow for the necessary labour supply to urban employers, while on the other hand it had to prevent "undesirable elements" from entering the towns along with the "desirables" ones. As has been pointed out above, the instruction of 14 January 1933 already contained some clauses to prevent passportisation from disrupting the labour-supply to industry, by explicitly granting seasonal workers the right to obtain a temporary identity paper and a short-term residence permit, both of which were subject to renewal upon request of the employer ${ }^{37}$ When the passport system was extended to the entire territory of the Soviet Union with the decree of 28 April 1933, it was similarly made sure that the supply-lines of rural labour would remain open. Under the stipulations of the decree rural residents arriving for a long-term or permanent stay in a passportised area could take out a passport valid for one year at their former place of residence, and register for a residence permit in a passportised area on production of a document stating the reasons for their stay. After a year they could exchange their temporary passport for a full three-year passport issued at their new place of residence. The details as to who would (not) qualify for a residence permit were to be laid down in specific police instructions regulating propiska. ${ }^{38}$

Thus, in this first stage, the passport system envisaged a considerable degree of control over population flows into the passportised areas, and the police leadership appears to have had high expectations regarding the extent to which the passport administration would bolster the efficiency of police work. ${ }^{39}$ However, as soon as the priority aims of the system had been achieved, and the main strategic towns and areas had been purged of "hostile elements" and non-working mouths, the aspirations of the regime concerning the passport system seem to have been scaled down. By the time that the second round of passportisation started, which targeted the non-regime areas, the crisis in the country had abated somewhat; production was on the rise again, and the urban population was decreasing of itself because of the strict limitations on hiring and state control over wages that had been established at the end of $1932 .{ }^{40}$ Food supply of course remained a bottleneck, but the first round of passportisation had undoubtedly reduced the claims on the supply system to some extent, and when it became clear that the next harvest would be good, the sense of outright emergency must have disappeared. Further passportisation was not called off, but where it concerned the non-regime areas it was carried through much more half-heartedly. No good legal basis for either the issuing of passports, or propiska in these towns was set up; instead, part of the

\footnotetext{
37. SZ, 3 (1933), art. 22.

38. SZ, 28 (1933), art. 168.

39. P. Hagenloh, art. cit: 297.
}

40. Cf. R. W. Davies, Crisis and progress in the Soviet economy, 1931-1933 (Basingstoke: Macmillan, 1996): 370-377, 390-398, 409-419. 
initially much more specific instruction of 14 January 1933 was declared to be applicable, and it was left at this for the rest of the 1930s, apart from the odd reminder that in these areas passports should be issued irrespective of social origin. ${ }^{41}$

As a result, the police and the OGPU were expected to run what was essentially a half-finished system of population registration. Whereas it was properly defined which persons were to be refused a passport in regime-towns during the phase of actual passportisation, this was not the case with the limitations on settlement that were to be in force in these areas afterwards. Although I have not been able to track down the central OGPU directive on the issue, the directive governing propiska in the regime-town of Sverdlovsk, which was obviously closely modelled on a central instruction, did not really hold any serious limitations in settlement, other than the requirements for arrivals to be in the possession of a passport, and to be able to document the purpose of their stay. ${ }^{42}$ This is not to say that there were no such limitations in practice. What seems to have been the case is that the instruction of 14 January 1933, governing the issuing of passports in regime-areas, was widely used by the OGPU and the police as the normative act concerning propiska as well, in the sense that those categories of persons listed as ineligible for a passport were also held to be ineligible for propiska. ${ }^{43}$ As we will see later on, this created some difficulties because the categories of the January 1933 instruction were not always equally well-tailored to the needs of screening persons that arrived from other areas.

The single largest problem, however, that the OGPU faced in running the halffinished passport system that was put in place in 1933, was how to separate the "desirable" from the "undesirable" among arrivals in the possession of a passport. The social cleansing of the regime-towns during the first phase of passportisation had been based primarily on withholding passports to those that were to be evicted, which made the distinction between the "desirable" and "undesirable" a rather clear-cut one. This changed after the second round of passportisation, in which passports were handed out to all residents of non-regime areas, regardless of social background, as well as to those persons that had been evicted from the regimetowns, but not arrested or deported by the OGPU. Thus, the possession of a passport was no longer automatic proof of "social reliability," and this opened the way for persons that would not have been eligible for receiving a passport under the secret part of the instruction of 14 January 1933 to enter the regime-areas through what

41. For the decree governing the application of the instruction of 14 January 1933, cf. SZ, 28 (1933), art. 168. As far as I have been able to ascertain, no public statements were made concerning the universal issuing of passports in non-regime areas, but in classified communications the OGPU leadership raised the issue repeatedly. Cf. Istochnik, 6 (1997): 106; GARF, f. R-5446 (SNK SSSR), op. 15a, d. 1094, 1. 4

42. GASO, f. R-854 (URKM UNKVD po Sverdlovskoi oblasti), op. 3, d. 113, 1. 89.

43. At least on one occasion this interpretation of the instruction of 14 January 1933 was also made explicitly by Iagoda, head of the OGPU, himself. Cf. GARF, f. R-5446 (SNK SSSR), op. 15a, d. 1175, 11. 8-9. 
one could call "the backdoor," i.e. by taking out a passport in a non-regime area and then moving on to a regime-town. Exactly in order to prevent this, it seems that the commission that had prepared the introduction of the passport system in $1932 \mathrm{had}$ discussed the possibilities of noting down in all passports whether the bearer was eligible for settlement in a regime-area or not. ${ }^{44}$ For whatever reason, though, the idea was discarded at the time, and instead the eventual passport laws contained all sorts of clauses that aimed at preventing earmarking people by entering incriminating information directly into their passports. ${ }^{45}$ As a result, the great majority of passports in circulation must have contained few if any clues for the police to determine whether the passport-holder was entitled to settle in regimeareas or not. In view of this, the OGPU and the police relied on two other methods for screening arrivals in regime-areas, and filtering the "undesirable elements" from among them.

In the first place an elaborate system of card-catalogues was set up, which contained not only information on whom had been issued or refused a passport at which points in time and in which places, but also any incriminating information on the person that had come to light during the passportisation procedure, but that could not be entered in the passport itself. ${ }^{46}$ As far as the little available evidence permits us to say, the information in this card-catalogue appears to have been stored only locally, in the sense that it was not routinely circulated through the OGPUapparatus, but supplied upon requests for information from police authorities elsewhere. Thus, in order to find out whether a certain person arriving in a regime area from a non-regime area did have any stains on his record, the police would have to send out a request for information to the locality where the passport of the person concerned had been first issued.

As a further instrument for filtering those that came to work in regime-areas, the OGPU also tried to channel the influx of labour recruits from the countryside as much as possible through the national scheme for the "organised recruitment of labour" (orgnabor), and refused propiska to those who arrived on their own accord, even if they were in the possession of a passport and a document from their kolkhozy stating their permission to leave. Asked upon to defend this position after a May 1934 complaint by the Council of People's Commissars of the Ukrainian Soviet Republic that the OGPU obstructed the labour supply to industry, Iagoda based his argument on the clause in the secret part of the instruction of 14 January 1933 that forbade the registration of persons that had arrived from other towns or

44. GARF, f. R-5446 (SNK SSSR), op. 18a, d. 845, 1. 28.

45. Cf. N. Moine, art cit.: 595-596. Persons that were refused a passport in a regime-town were to be handed back the documents they had submitted in order to establish their identity intact, without these bearing any trace of the refusal of a passport. The same went for people that were refused propiska in a regime-area; their passports were not supposed to show this. Some passports might have contained incriminating information concerning the bearer's former social background (of the type "worker, former kulak") as by force of an instruction of May 1933 , but it is unclear to what extent this decree was really implemented.

46. P. Hagenloh, art. cit.: 297. 
the countryside after 1 January 1931, without a formal invitation from their future employer, and that were found to be "flitters" or "disorganisers of production." Among those "collective farmers" arriving on their own accord, i.e. not through orgnabor, he argued, there are very few "real collective farmers," and most of them are in fact "flitters," if not outright "class-alien and criminal elements" who have been refused passports in regime-towns and now try to reenter with a passport procured in a non-regime area, where passports are issued regardless of social background. Therefore, the linking of propiska to orgnabor should not be abandoned, since it "allows for an on-the-spot check-up on the social characteristics of each and every recruited worker." 47

Thus, once the first phase of actual passportisation was completed and the population of the regime-areas had been cleansed of "undesirable" and "socially harmful elements," the OGPU and the police tried to keep these areas "clean" by screening new arrivals through an intricate system of registration, involving cardcatalogues and orgnabor-contracts, that ran parallel to the actual passport system. This proved problematic, however, and the OGPU leadership saw control over population flows into the regime-areas they were supposed to protect, slowly slipping through their fingers. To start with, in September 1934 the protective screen that the OGPU had erected around the regime areas was punctured when a special decree was issued that authorised the propiska of kolkhozniki arriving in the towns on their own accord, if in the possession of a passport and a leave-permit from their kolkhoz, in other words, authorising exactly that which Iagoda had vehemently protested against only a couple of months earlier. This move was no doubt largely inspired by anxiety on the part of the authorities over the supply of rural labour to industry; in spite of the fact that it had been approved under the ruling "secret," the decree was published in full, which suggests that the party and state leadership specifically wanted to draw the population's attention to it. ${ }^{48}$

This decree must have significantly undermined the efforts of the OGPU/ NKVD leadership to systematically screen arrivals from the countryside on their social and political reliability, particularly so because there are some indications that the decree might have been interpreted much more liberally by local police authorities than had been intended. The crux of the problem was that there seems to have been considerable confusion within the police about the distinction between the issuing of passports on the one hand, and propiska on the other. Obviously, this confusion must have stemmed largely from the fact that the instruction of January

47. GARF, f. R-5446 (SNK SSSR), op. 15a, d. 1175, 11. 1-14; quote from 1.9.

48. The remarkable thing about this decree is that it was proposed to Sovnarkom by the OGPU itself, shortly after it had protested vehemently to a similar suggestion by Sovnarkom. Probably pressure had been brought on the OGPU after intervention by one or the other institution or party leader pushing for the interests of industry. Cf. GARF, f. R-5446 (SNK SSSR), op. 15a, d. 1175, 11. 1-14; published in: $S Z, 49$ (1934), art. 389. In July 1935, though, the NKVD was able to block a request by the Leningrad local authorities to extend the workings of this decree to non-kolkhoz peasants arriving in the towns for work, on the grounds that this would bring too many "socially alien" and "criminal elements" into the regime areas. Cf. GARF, f. R-5446 (SNK SSSR), op. 16a, d. 1332, 11. 1-6. 
1933, technically speaking regarding exclusively the issuing of passports, was, as we have seen, widely used as the main normative act concerning propiska as well. The issue was, however, by no means a merely technical one. As becomes clear from a letter that the Dnepropetrovsk District Party Secretary Khataevich sent to Sovnarkom and the Central Committee in December 1935, the confusion between the issuing of passports and the registering of passports (propiska) could have rather far-reaching repercussions in practice.

The letter complained about the problems posed by the passport regulations for the recruitment of workers for industry in the regime-town of Dnepropetrovsk in the Donbass, quoting as examples the fact that no passports could be issued to family members that wanted to join workers already employed in Dnepropetrovsk, as well as to kolkhozniki that arrived on their own accord. Therefore Khataevich asked for permission to lift these restrictions. Asked for comments, Iagoda pointed out that existing instructions did not impose any limitations on the propiska of family members as long as they were in possession of passports issued at the place of former residence. But handing out passports to persons that arrived in Dnepropetrovsk without documents, should not be allowed, "as this contradicts the very essence of the passport law." Similarly, he pointed out that the decree of 19 September 1934, that Khataevich was seemingly unacquainted with, already allowed for the propiska of kolkhozniki that arrived on their own accord. "As for persons that arrive without passports it speaks for itself, however, that such "kolkhozniki" should not be allowed access to regime areas, [...] but should be arrested in order to determine their identity." 49

Thus, even in a major industrial centre and regime-town like Dnepropetrovsk the police obviously routinely confused the moments of propiska and that of the actual issuing of passports. In this case, Khataevich was informed of the exact regulations in existence, but it seems legitimate to assume that in other places the same confusion must have reigned, and that, consequently, the decree of 19 September 1934 might very well have been interpreted by local police authorities as an authorisation to hand out passports to arriving kolkhozniki, thus eliminating all possibilities to retrieve incriminating information on the persons concerned from their former places of residence. Indeed, to a large extent it was the insufficiently rigid, and at times even incorrect implementation of central instructions that undermined the efficiency of the passport system in screening the population flows into regime areas..$^{50}$ Already during the passportisation of the first half of 1933, instances were reported in which local police authorities, in case of doubt as to the "social reliability" of particular persons, simply issued temporary identity papers, instead of taking the necessary steps to establish the identity of the

49. GARF, f. R-5446 (SNK SSSR), op. 18a, d. 894, 11. 3-6.

50. According to Paul Hagenloh, during the years 1934-1936 the central OGPU/NKVD leadership seems to have had in general a difficult time directing, controlling and cajoling the militsiia into fulfilling central directives, and the local police were able to substantially define the parameters of "Soviet policing" in this period. Cf. contribution of Paul Hagenloh to this issue. 
persons concerned with more certainty. ${ }^{51}$ Much more importantly, it seems that, when registering new arrivals, local police authorities hardly if ever put out the requests for information from the card-catalogue at the place of residence that should have been more or less standard procedure.52 This was fundamental, because it touched at the very heart of the system of fil 'tratsiia that the passport system rested upon, and it effectively meant that, in a lot of cases, people must have been able to rid themselves of stains on their record by moving to another area, and thus circumvent the restrictions on settlement in regime-localities that existed for certain categories of people.

One of the consequences of this failure to implement the passports controls in a systematic way, was that the police resorted ever more often to ad-hoc sweeps and raids of urban areas to weed out "undesirable" and "socially harmful elements" that had slipped through the mazes of the net. As recent studies show, such purging campaigns of passportised areas in fact became the predominant policing tactic during the mid-1930s. What is interesting is that these sweeps primarily targeted all sorts of social marginals and criminals, rather than persons that had arrived for work without the necessary papers, "kulaks" or other suspicious rural dwellers, as had been the case during the initial phase of passportisation. ${ }^{53}$ A sample of the daily police reports on crime in the regime-city of Sverdlovsk for the year 1935 shows for example how the police was actively checking passports, singling out and arresting or evicting "thieves," "bandits," "alcoholics," "homeless," persons without a fixed job, "spekulianty," and, particularly, ex-convicts or people that had escaped from labour camps, work settlements or other places of exile. ${ }^{54}$ In regime-areas these sweeps were facilitated by the existence of special OGPU, and later NKVD, extrajudicial passport troiki, in whose powers it was to withdraw passports that had been issued earlier on, and to sentence, deport and evict violators of the passport regime without going through court. But also in non-regime areas the police seems to have carried out sweeps and round-ups of social marginals, possibly on the basis of special decrees authorising such operations in specific areas.

Thus, amidst the failure to uphold the systematic application of controls over the influx into the passportised areas and widespread extra-judicial sentencing of passport violators, the passport system had become much more of a hands-on system of social cleansing than the systematic instrument of social control the police had initially envisaged. By 1935 this led to a renewed attempt by Iagoda and the NKVD to bring some order into the matter and to tighten and facilitate control over population flows into the regime-areas. In a letter to Sovnarkom of December 1935, Iagoda signals the fact that, because of the absence of any incriminating

51. Tsentr Dokumentatsii Obshchestvennykh Organizatsii Sverdlovskoi Oblasti (TsDOOSO), f. 161 (Sverdlovskii gorkom VKP (b)), op. 1, d. 244,1.21.

52. Information of Paul Hagenloh, Paris, MSH, May 2000.

53. See the contributions of David Shearer and Paul Hagenloh to this issue, as well as P. Hagenloh, art. cit.

54. TsDOOSO, f. 161 (Sverdlovskii gorkom VKP (b)), op. 1, d. 453, 11. 1-320. 
information in the passport itself, "socially alien" and "harmful elements," as well as convicts having finished their terms, are able to worm their way into regimeareas by taking out "clean" passports in non-regime areas, where passports were issued to all applicants regardless of social background, and subsequently moving on to regime-areas. Therefore he proposes to put a special note, reading "for nonregime areas only" in the passports of all persons that, according to the instruction of 14 January 1933, were not allowed to live in regime-areas. Possibly, this attempt was also partly inspired by concern over the fact that, alongside the persons whose sentences had been commuted in the 1935 amnesty, in 1935-1936 the first "kulak" spetspereselentsy would reach the end of their terms and would try to find a place to settle down. Rather unexpectedly, however, the NKVD's proposal met with fierce resistance from the Procuracy, partly backed up in this by Molotov in his capacity as chairman of Sovnarkom. Although the Procuracy agreed that the proposed measure would facilitate control over population flows into the regime-areas, it seems to have considered the earmarking of all persons falling under the secret clauses of the instruction of January 1933 too severe and too drastic a step, and argued that the police should just make a more concentrated effort at implementing existing instruments of control. In the end the NKVD was only able to secure a note in the passports of certain categories of ex-convicts that would bar them from taking up residence in regime-areas. In August 1936 the instruction of January 1933 was amended to this extent..$^{55}$

This must have made it possible for the first time to really seal off the regimeareas for certain unwanted categories of persons, in this case ex-convicts, who could be identified instantly on the basis of their passports, without having to engage in the difficult and time-consuming procedure of putting out a request for information to the former place of residence or the place where the passport had been issued. In this sense the decree of August 1936 reflected the over-all hardening of the atmosphere in the country, which was by then already hovering on the brink of the Great Terror. A further measure to enhance the efficiency of the passport system was the introduction, in 1937, of photographs on passports, of which a copy was stored in the card-catalogue. ${ }^{56}$

This phase of more rigorous control seems to have lasted until September 1940, when the passport laws were completely overhauled and a new Passport Statute was adopted that considerably reduced the restrictions on settlement that had existed under the previous legislation..$^{57}$ These changes are not immediately apparent from the new law. The published part of the decree merely brought together the rulings of the various passport decrees of the years before into a single normative act. The secret part split up the regime-localities, which had grown

55. On Iagoda's attempt to introduce earmarking of non-regime passports and the ensuing bureaucratic infighting, cf. GARF, f. R-5446 (SNK SSSR), op. 18a, d. 845, 11. 1-34. On the authorities' concern over the imminent release of "kulaks" and other convicts, cf. O.V. Khlevniuk, op. cit.: 152.

56. $S Z, 70$ (1937), art. 328.

57. Sobranie postanovlenii i rasporiazhenii pravitel'stva SSSR, 24 (1940), art. 591. 
considerably in numbers over the decade, into two categories with different restrictions on settlement. The areas falling into the first category were closed for persons that had been convicted for counter-revolutionary or criminal offences, refugees from abroad, people that had arrived without a formal invitation for work, persons that were not engaged in socially useful work (with the exception of pensioners, the disabled, and dependants of working people), and, finally people that had been convicted for hooliganism. The second category of regime-localities, to the contrary, were to be closed only to people convicted for counterrevolutionary and/or criminal offences. The true extent of this partial relaxation in settlement limitations becomes clear only if one has a closer look at which areas fell into which category. What turns out is that the strict settlement norms of the first category, which had been in force in all regime-towns before 1940, were now to be applied only in a small number of places. Apart from Moscow, Leningrad, Kiev and other republican capitals, these consisted for almost half of kurorty and seaside resorts in the Crimea and the Northern Caucasus, plus the border-zones of the country. Most conspicuously absent in the first category were the main industrial towns and areas, which all fell into the second category that comprised the overwhelming majority of the, in total, 175 towns and 460 raiony that had acquired regime-status by 1940 . Without going deeper into this here, this suggests that the relaxation in settlement limitations brought by the new passport statute of 1940, might have been at least partially an attempt to remove obstacles in the way of persons that were willing to go and work in industry, which was again screaming for manpower as the effects of war-preparations made themselves felt..$^{58}$

\section{Monitoring population flows}

As we saw, one of the professed aims of the introduction of a system of internal passports and urban residence permits had been to improve population registration, and hence, population statistics. Both the investigations of the Balitskii commission, which prepared the passport laws of 1932, and the survey held by the Central Administration for Economic Accounting (Tsentral'noe Upravlenie Narodnokhoziaistvennogo Ucheta-TsUNKhU) in the same year revealed a considerable degree of inaccuracy in the existing system of population registration..$^{59}$ This was confirmed during the passportisation campaign of 1933-

58. The secret clauses of the law are rendered in the NKVD-instruction laying down the rules for the application of the new Passport Statute. Cf. GARF, f. R-9401 (NKVD SSSR), op. 12, d. 233, tom 1, 1l. 1-65 (With thanks to Terry Martin for this reference), as well as in N. Moine, art. cit.: 597 . For details on which areas were included in the two categories and for figures on the total number of regime-localities, cf. Istochnik, 6 (1997): 111-113. For comparison: the total number of towns in the Soviet Union as of July 1939 was 931, and the number of raiony 3,526. Cf. RGAE, f. 1562 (TsSU SSSR), op. 20, d. 171,1.33. On the renewed labour shortages of 1938, cf. J. Barber, "The development of Soviet employment and labour policy, 1930-1941," in: David Lane, ed., Labour and employment in the USSR (Sussex, 1986): 56; D. Filtzer, Soviet workers and Stalinist industrialization (London, 1986): 127-128.

59. Istochnik, 6 (1997): 104-105; GARF, f. A-374 (TsSU RSFSR), op. 23, d. 198, 11. 1-227. 
1934, when it was found that scores of cities actually had far fewer inhabitants than had been expected on the basis of the available population data. Magnitogorsk, for example, was thought to have around 250,000 inhabitants, but passportisation revealed that in reality only 75,000 people were living at the site, and Sakhalin "yielded" only 60,000 persons, instead of the expected 120,000.60

In order to improve the situation a system of population registration was set up that relied on double registration vouchers (otryvnye talony) that had to be filled out by the police for every person taking up residence (propiska) in a passportised locality. One half of the voucher was filed at the local police station, and the other half was passed on to the TsUNKhU apparatus, which then processed the data into agglomerate population statistics for each town separately, for all the towns of a province (oblast') taken together, and for the separate union-republics and the union as a whole. Apart from name, address, date and place of birth, the vouchers contained data on the social background of the person taking up residence and whether the person concerned arrived from the countryside or from another urban area. At the departure side this was matched by a similar set of vouchers that recorded the same data for every person annulling or changing residence (vypiska). After separating the vouchers of those persons who were merely changing residence within one locality from those who were arriving from elsewhere, this yielded a set of flow statistics on the ratio between urban arrivals and departures (mekhanicheskoe dvizhenie naseleniia), which, in combination with the data on urban births and deaths (estestvennoe dvizhenie naseleniia), would allow TsUNKhU to keep track of the fluctuations in the number of inhabitants of the passportised areas on a yearly basis, and, in the end, to calculate the size of the urban population from this. ${ }^{61}$

This system of population registration was first put to the test with the population census of 6 January 1937, and it turned out that it suffered from rather serious deficiencies. Polling revealed widespread discrepancies between the census results and the population forecasts that had been produced on the basis of the dayto-day registration of births, deaths, and internal migration, both for the size of the urban population as a whole and for the number of inhabitants of individual towns. To complicate things, the discrepancies did not show a uniform pattern. Whereas in aggregate terms the census yielded a smaller urban population than had been expected, the reverse was the case in, for example, Moscow, where 200,000 more

60. Of course, these differences were also partly due to the fact that considerable numbers of people who could not reasonably expect to qualify for a passport and propiska avoided registration altogether and left the towns, but this alone could not have been enough to explain for the huge overestimates of the urban population size. For the city of Magnitogorsk, for example, the same report mentioned that around 35,000 persons had left on their own accord on the eve of passportisation. Unfortunately it remains unclear whether the NKVD had meant the figure of 75,000 inhabitants to include these persons, but even if it hadn't, and the population of Magnitogorsk would thus have been 110,000 before passportisation, this figure still falls far short of expectations. Cf. N. Werth, G. Moullec, op. cit.: 45.

61. Cf. N. Moine, art. cit.: 590. For internal TsUNKHU instructions concerning the registration procedure, cf. RGAE, f. 1562 (TsSU SSSR), op. 20, d. 119, 11. 17-29, 71-72, 81, 86, 104. 
people were counted than had been estimated beforehand..$^{62}$ Obviously, there was something fundamentally wrong with the population registration data on which the forecasts had been based. What was wrong with them became the issue of a fierce debate as the tragic events surrounding the 1937 census unfolded. The story of this census has been carefully documented in recent publications. ${ }^{63}$ With the largely unregistered excess mortality related to the repression and famine of preceding years showing up clearly, the population count fell considerably short of Stalin's forecasts, and "disappointment" with the figures led him to suppress the results and arrest the statisticians who had organised and carried out the census.

Feeling the heat, TsUNKhU desperately tried to account for the inaccuracy of its forecasts. As far as the migration data were concerned the statisticians knew very well where the problem lay, namely with a wildly inaccurate registration of urban arrivals and departures by the local police authorities, which had already been signalled in a survey of July $1936 .{ }^{64}$ Now, trying to document their case better in order to shift the blame for the "defective" census results to the police, TsUNKhU carried out further check-ups in the regions, which revealed that the accuracy with which the police handled both registration and the processing of the registration data, left much to be desired. The police was found to deploy little or no activities to check whether people were actually living at the place they were registered at, and many houses and barracks harboured scores of people without propiska. Besides, it turned out that large numbers of people, although being registered as such, did in fact not live there anymore, without having annulled their residence with the police. As a result, considerable discrepancies existed between registration data and actual numbers of residents. ${ }^{65}$

The fate of the statisticians had already been sealed, however; over the late spring and summer of 1937 a wave of arrests swept through the TsUNKhU and UNKhU apparatuses, clearing out virtually all personnel that had somehow been involved with the 1937 census. A large number of them were shot-others served long terms in prisons and forced labour camps. ${ }^{66}$ The police leadership, whilst acknowledging the less serious deficiencies in their handling of urban population registration (no doubt they were about the only ones who could get away with this in the year 1937), obscured the graver ones. In a letter to the regional and local police authorities of September 1937 the Central Police Department of the NKVD seized upon non-annulment of residence at departure as the principal factor contributing to the inaccuracy of urban population registration data. In so far as the

62. RGAE, f. 1562 (TsSU SSSR), op. 329, d. 131,11. 10-11.

63. V. B. Zhiromskaia, I. N. Kiselev, Iu. A. Poliakov, Polveka pod grifom "sekretno." Vsesoiuznaia perepis' naseleniia 1937 goda (Moscow, 1996): 28-62; Alain Blum, "À l'origine des purges de 1937, l'exemple de l'administration de la statistique démographique," Cahiers du Monde russe, 39, 1-2 (janvier-juin 1998): 169-196.

64. RGAE, f. 1562 (TsSU SSSR), op. 20, d. 119, 1. 130; op. 329, d. 131,11. 10-11.

65. RGAE, f. 1562 (TsSU SSSR), op. 329, d. 132, 11. 70-73.

66. V. B. Zhiromskaia et al, op. cit.: 138. 
persons who did not annul their propiska when changing residence left the towns, it resulted in the inclusion of an unknown amount of "dead souls" in urban population statistics. In so far as it concerned persons who changed residence within one and the same town, or that moved to another town, it led to a certain degree of doublecounting when these persons registered for a second time at their new place of residence. In both cases, inflated urban population figures were the net result. In order to remedy the problem and to avoid further double-counting the regional and local police authorities were instructed to demand proof of annulment of former residence from persons taking up propiska from then on. ${ }^{67}$

Meanwhile, it was not at all clear to what extent non-annulment of propiska upon departure really was to blame for the inaccuracy of the urban population registration data. Check-ups usually also revealed persons without propiska in numbers almost just as large as, or in some cases even larger than those found to have departed without annulling residence. ${ }^{68}$ Unclear is whether this concerned people who were formally registered as residents elsewhere, or people who had arrived in the towns without ever taking up formal residence, and consequently whether these persons were accounted for at all in urban population statistics or not. In any case though, they could cause potentially large distortions in the accuracy of population statistics in relation to the actual number of people present. One may well wonder for example if the divergence between census results and forecasts in Moscow was not caused largely by the presence of people who were living in the city without ever having taken up residence there. In relative terms the 200,000 "extra" persons that were discovered at the time of the 1937 census represented around $5 \%$ of the Moscow population of that time. ${ }^{69}$ And this figure does not even take into account yet those persons that were similarly living in Moscow without propiska, but that managed to evade the population count altogether. Indeed, it seems more than likely that the police authorities emphasised double-counting and non-annulment of residence so strongly in order to draw attention away from the fact that, apparently, they exercised a far from all-encompassing control over population influx into the passportised localities.

By and large, they seem to have got away with this. Although TsUNKhU carried out a second survey of the accuracy of registration procedures over the first quarter of 1938, and found that little had improved, it probably lacked the political clout after its falling from grace in 1937 to denounce the NKVD and the police for its lax application of the passport procedures. ${ }^{70}$ TsUNKhU inspectors faced active obstruction by police officials in carrying out check-ups on the application of registration procedures, and in October 1938 the Central Police Department (GURKM) of the NKVD decided unilaterally not to fill out registration vouchers

67. RGAE, f. 1562 (TsSU SSSR), op. 20, d. 119, 1. 130.

68. Ibid., 11. 122-123.

69. Calculated on the basis of the population data for Moscow as listed in the 1937 census results. Cf. V. B. Zhiromskaia et al, op. cit.: 56.

70. GARF, f. A-374 (TsSU RSFSR), op. 23, d. 413, 11. 1-199. 
any longer for persons arriving in the towns for short-term stays, because, allegedly, it was this category that accounted predominantly for the non-annulment of propiska when leaving or changing residence, and hence for the inaccuracy of urban population registration data. ${ }^{71}$ Gradually, control over the application of registration procedures was thus wrested from the statistical organs, and by 1939 TsUNKhU had come to the point where it had adopted the position of GURKM that non-annulment of propiska upon departure accounted for the inaccuracies of population statistics calculated on the basis of urban registration data, even if check-ups in the regions still revealed incomplete registration of both arrivals and departures. $^{72}$

In view of this it seems appropriate then to wonder whether the figures procured from the passport and propiska-based system of population registration really provided the party and state leadership with much insight at all into population movements to and from the urban centres. After all, this had been one of the professed aims of the introduction of the passport system back in 1932. In answering this question, it is necessary to separate two sorts of inaccuracy in the information procured from these migration statistics; on the one hand inaccuracies caused by deficiencies in the system of registration itself, and on the other hand inaccuracies in terms of the relation of registration figures to the actual situation. To start with the former, there was the problem of non-annulment of propiska upon departure. Sample check-ups by TsUNKhU on the accuracy of registration data in various regions and towns in 1938 give a rough indication of the order of magnitude of this phenomenon. A high of $16.5 \%$ non-annulment of propiska by persons that had in reality departed was registered in the town of Kazan and a low of $1.8 \%$ in the Kuybyshev district; in the majority of the other regions involved in the check-ups the corresponding figure hovered around the $10 \% .^{73}$

Apart from these systematic distortions, there is the question to what extent the registration data expressed the actual state of affairs. As we have seen, periodic check-ups also revealed considerable numbers of people living in the towns without a valid propiska for the place they were de facto residing at. The same survey of 1938 referred to above also allows us to get an indication of the magnitude of this phenomenon, with the percentage of illegal immigrants ranging from a low of $2.4 \%$ of the people involved in the check-up in the Kursk district to a high of $15 \%$ for the republic of Dagestan in the North Caucasus. ${ }^{74}$ Unfortunately, no clear trend is emerging from the corresponding figures for the other regions, but further evidence (as well as common sense) suggest that the major regional urban-

71. RGAE, f. 1562 (TsSU SSSR), op. 20, d. 119.11. 7, 7ob, 8 .

72. GARF, f. A-374 (TsSU RSFSR), op. 23, d. 465,11. 1-214.

73. GARF, f. A-374 (TsSU RSFSR), op. 23, d. 413, 11. 4-7, 14-15, 22, 47, 143-144, 154. These check-ups generally involved only a few hundred people in a couple of houses or barracks, so they themselves contain a potentially large margin of error, but at least they give a direct indication of the accuracy of the registration data at the grass-roots level.

74. GARF, f. A-374 (TsSU RSFSR), op. 23, d. 413, 11. 4-7, 14-15, 22, 47, 143-144, 154. 
industrial centres were harbouring the largest contingents of persons without propiska. When analysing the migration figures for 1939 TsUNKhU discovered that for a whole series of towns the number of people that had indicated to move to those towns upon departure from other urban centres was higher than the number of people who eventually registered as arrivals in those towns. For Moscow for example, there were almost two and a half times more "departures to Moscow" registered than the actual number of people who eventually registered their arrival in Moscow (on every 1,000 registered arrivals there were 2,396 registered indications of departure to Moscow). Similar divergences between departure and arrival data were observed for other cities and urban areas, like Leningrad (on every 1,000 registered arrivals, there were 1,655 registered indications of departure to Leningrad), and the Kiev district (1,327 indications of departure to the urban centres of the Kiev district for every 1,000 registered arrivals). ${ }^{75}$

TsUNKhU presumed that these discrepancies should be attributed to the fact that a certain part of those who had indicated to go to a particular town had in the end found it impossible to take up residence there because of limitations imposed on settlement by the passport regime, a lack of housing and other factors, and had therefore taken up residence in nearby rural areas. But it seems of course extremely likely -and TsUNKhU obviously understood this, but could not say it- that at least part of these people that had gone missing on the road, ended up in the towns they had indicated anyway, but as illegal immigrants. This means that, particularly in the larger urban centres, it could very well be that the actual number of urban arrivals was in fact higher than the registration data suggested. Thus, urban population registration data at the same time both over- and underestimated urban arrivals. Non-annulment of propiska upon departure inflated the number of residents and the net population shifts from village to town, while the limitations on propiska in some towns gave rise to an unknown number of illegal and unregistered arrivals that did not show up in the statistics. To some degree, these two factors of inaccuracy of course compensated for each other, in the sense that the place of people who had left without registering so was taken by people who had arrived without registering so, but particularly at the level of individual towns it must have been practically impossible to assess the degree to which such compensation occurred..$^{76}$

Summarising, it can be concluded that the system of population registration that was set up could only to a limited extent provide the state and party leadership with the information on the size and fluctuation of the urban population that they had wished to obtain when introducing internal passports and urban residence permits

75. RGAE, f. 1562 (TsSU SSSR), op. 20, d. 171, 11. 3-4, 15.

76. The sample check-ups from the 1938 survey show that in some cities or regions the number of unregistered departures and unregistered arrivals kept each other more or less in balance, while in other towns this was not the case. In the sample for Kazan for example, 22 persons without propiska were found against a total of 109 persons that had left the town without registering their departure. The net effect was that instead of the expected 662 persons in fact only 575 persons were living in the buildings involved in the check-up. Cf. GARF, f. A-374 (TsSU RSFSR), op. 23, d. 413,1. 154. 
back in 1932. The irony of the situation was that to some extent it was the restrictive character of the passport regime itself that caused for a certain degree of inaccuracy of urban population statistics, in the sense that it forced part of the migration flows into the illegal, and hence unaccounted for, sphere. On a more structural basis the system of population registration set up after 1932 suffered from the fact that it tried to track population flows in society with only one point of measurement; in the end, the absence of a system of population registration in the countryside made it impossible to check the validity of the urban registration of arrivals and departures. ${ }^{77}$ All this seems to suggest that the improvement of population registration had not been one of the priority aims of the regime in introducing the passport system back in 1932. In any case the inaccuracies of the population statistics based on the urban registration data do not seem to have been a cause of great concern for the country's leadership, with the exception of the period around the census of 1937. This means that they were either content with the sort of rough indication that the migration statistics could provide, or that they basically did not care.

\section{Levers of control}

One of the conclusions that can be drawn from the findings laid out in the preceding paragraphs, is that, whilst effective in achieving its short-term repressive aims, the passport system faced much larger difficulties in implementing the more systematic forms of control over population movements that had been envisaged at the outset. Both in monitoring and in filtering population flows initial attempts at achieving fairly pervasive forms of control floundered in the course of the decade, not in the last place due to a lax and incomplete application of established registration procedures by regional and local police authorities. Not only did part of the population movements into the passportised areas go unregistered and hence uncounted, they also often went unchecked for the presence of the very "socially unreliable elements" the regime sought to bar from the passportised areas. These findings might cause surprise, given the fact that the passport system was run by the all-powerful NKVD with its all-pervasive secret police activity. To some degree, however, the failure of the passport system to achieve systematic control was also related to the fact that it was run by the NKVD, as the secrecy surrounding all repressive activities of "the organs" did not always contribute to the effectiveness of the passport system. This is illustrated best by the fact that one of the main obstacles on the road to an effective screening of arrivals in regime-areas was the peculiar set-up in which incriminating information on the bearer was not entered

77. In view of this, Kraval', head of TsUNKhU, proposed to Molotov, in March 1937 (i.e. shortly before his downfall), to extend the passport system to the rural areas in order to improve the system of population registration as a whole. Cf. N. Moine, art. cit.: 591. It would take until 1974 for this measure to be realised. Cf. Istochnik, 6 (1997): 119-121. 
into the passport itself, but in a secret shadow system of card-catalogs, which then failed to produce the desired results. In this sense the inefficiency of the passport system in the 1930s offers one more illustration of the difficulties of the Stalinist regime in this period with the full and undistorted implementation of the more complicated and complex of its policies at the lower levels of the state and party apparatus. But there are further conclusions to be drawn that tell us much more about the nature of state control in Stalinist society than the mere observation that it was not always equally effective or all-encompassing.

Harking back to the set of interlocking decrees adopted during the 1932-1933 crisis to purge certain areas of "unreliable elements," the passport laws were designed to be an instrument of control that could be put in place whenever it was found expedient to rid the one area or the other of potential "enemies" or troublemakers, and to prevent people that could become so from settling there. The passport system was therefore from the very outset a system of selective, rather than all-encompassing control over population flows. As a system of population registration it only measured population movements to and from the urban areas. As a system of population control it only aimed at limiting access to areas that were considered to be of strategic importance - the so-called "regime" areas. Meanwhile, the fact that the actual running of the system was put in the hands of the NKVD, subject only to a limited extent to legal constraints, warranted that it could be applied whenever and wherever deemed necessary. From this, the Stalinist leadership appears less concerned with achieving full control over access to regime areas when introducing the passport system, than with acquiring the possibility to deny rights of settlement in these areas to whatever category of persons it would find expedient to move against. It seems more than likely, for example, that it were these kind of considerations that lay at the root of the decision not to put any indications of settlement limitations in the passports themselves, because this would preclude the possibility to change the categories of persons not eligible for settlement in regime-areas according to future needs without re-issuing all passports. Similarly, the categories of persons concerned were never made public, so as to retain a free hand to change them as the needs of the moment dictated, without having to publicly explain for these changes.

This way, the introduction of the passport system appears more as a matter of putting into place levers of control, than of imposing control as such. And a formidable lever of control it was. The fact alone that the categories of people who were not eligible for propiska in the regime towns were never made public must have given the OGPU/NKVD considerable leeway in deciding whom to evict from these areas, particularly during the early phase of outright passportisation, which targeted such broadly defined categories of people that they were potentially applicable to almost anyone. During later years, when the list of "unwanted elements" was narrowed down somewhat to more specific categories, such as persons with criminal records, the police must have lost some of its manoeuvring space in this respect, also because the Procuracy became increasingly active in dealing with police abuses of the passport 
laws. ${ }^{78}$ Nevertheless it is obvious that the passport system must have increased the power of the police over the public tremendously, if only because of the fact that nobody knew whether he or she fell into the secret categories that were forbidden to live in certain areas. Nobody would therefore for example ever be able to ascertain whether he or she was legitimately told to leave or not. Similarly, many people that were initially allowed to take up residence must have lived in constant uncertainty as to whether their passports and residence permits would not suddenly be withdrawn and they themselves be evicted as "undesirable elements."

A glimpse of the psychological pressure stemming from the secrecy surrounding the existence of incriminating information on one's person is provided by the recently unveiled diary of Stepan Podlubnyi, son of a dekulakised peasant that had managed to escape to Moscow with the help of forged documents and to build up a respectable existence as a worker there. When passportisation came, which Podlubnyi correctly interpreted as a purging campaign, he longed for the clearly identified and unquestioned social identity that the passport would bring him, but when he had finally received the document publicly marking him down as a worker, it failed to ease the fears of those stains on his record that were somewhere out there surfacing one day to bring to light his "undesirable" past. ${ }^{79}$ The story of Podlubnyi might be representative for many others during the 1930s. Whether deliberately so or not, the lax application of restrictions on propiska meant in practice that a considerable part of the urban population could at any given time be thrown out of certain areas for "violating" the passport laws, if the regime or the police would find this expedient. And it is here that we arrive at the very essence of Stalinist state control over the population, which was effective not because it achieved a total and constant degree of control over people's affairs, but because the levers of control were in place to deeply influence people's lives at decisive moments.

International Institute of Social History

Cruquiusweg 31

1019 AT, Amsterdam

The Netherlands

e-mail :kessler@inbox.ru

78. Earlier on, we already caught a glimpse of the constant struggle between the Procuracy and the OGPU-NKVD around the issue putting an indication of former conviction in passports. This struggle seems to have started immediately after the Procuracy had been created in 1934 with an attempt by Akulov, the Procurator of the USSR, to check-up on the validity of police decisions on the issuing of passports and residence permits to individual citizens. After prolonged bureaucratic infighting the Council of People's Commissars, or Sovnarkom, resolved the matter in favour of the OGPU. Cf. GARF, f. R-5446 (SNK SSSR), op. 15a, d. 1094, 11. 1-18.

79. As rendered in J. Hellbeck, "Fashioning the Stalinist soul. The diary of Stepan Podlubnyi, 1931-1939," in: Sheila Fitzpatrick, ed., Stalinism..., op. cit.: 85-86. 